\title{
EVERYDAY SPATIALITIES OF INTERSECTIONAL SOLIDARITY AND ACTIVISM
}

\author{
MAARTEN LOOPMANS* (iD) , GAVIN BROWN** (iD) \& VALERIE DE CRAENE ${ }^{* * *}$ (iD) \\ * Division of Geography and Tourism, Department of Earth and Environmental Sciences, University of \\ Leuven, Celestijnenlaan 200E, 3001, Leuven, Belgium.Email: maarten.loopmans@kuleuven.be \\ "School of Geography, Geology and the Environment, University of Leicester, University Road, Leicester, \\ LE1 7RH, United Kingdom. Email: gpb10@le.ac.uk \\ **** Division of Geography and Tourism, Department of Earth and Environmental Sciences, University \\ of Leuven, Celestijnenlaan 200E, 3001, Leuven, Belgium. E-mail: maarten.loopmans@kuleuven.be \\ (Corresponding author)
}

Received: April 2020; accepted April 2020

\section{FEMINIST GEOGRAPHIES OF INTERSECTIONALITY}

Over the past decades, intersectionality has been hugely influential in gender studies and feminist theory (Weldon 2019). Intersectionality offers a powerful theory to study social inequality, politicsand identification simultaneously (Anthias 2012; Collins \& Bilge 2016). As was first spelled out by Crenshaw (1989), building on the work of the Combahee River Collective (1983), intersectionality draws attention to the ways in which axes of social hierarchies - such as class, gender or race - donot operate separately but mutually influence each-other.

From its origins in North-American Black feminist struggles, intersectionality has fanned out into different theoretical and political directions. While sharing an interest in the way social differentiations combine to construct social hierarchies and power differences, these approaches can differ in their conceptualisation and political ambitions (Choo \& Ferree 2010). Feminist geographers too have been inspired by intersectional theory, not least because place and space have always been an important, although sometimes implicit venture point in intersectional thinking (hooks 1984; 1990; Davis 1983; Valentine 2007; Brown 2012; Williams 2014). Nonetheless, explicit engagement with intersectional theory by geographers more generally came rather late (Valentine 2007; Hopkins 2018). This editorial briefly reviews some of the ways geographers have engaged with intersectional theory.
Feminist geographers have primarily focused on theoretical elaborations of the intersection of structuring conditions; and on the elaboration of case studies to analyse the lived experiences of intersectionality at the level of the individual (Valentine 2007; Rodóde-Zárate \& Baylina 2018). As we outline below, geographers have deployed intersectionality to understand the connections between the production of space and the reproduction of power. Intersectionality has urged geographers to rethink places not just as territories governed from above, but also as relational intersections characterised by emergence and connections (Prins 2006; Featherstone 2012). This work has also focused on the intersection of power relations, exclusion and solidarity and their production in place-based interactions (Knapp 2005) through propinquity and connectivity in everyday places (e.g. Featherstone 2012; Janská et al. 2017). Looking at these inequalities and their interaction with places (Barber 2015; May 2015; Williams 2014) through the lens of intersectionality, place reveals itself as a crucial nexus point in the production of intersectional exclusion and solidarity (Rodo-de-Zarate 2017, 2016; Silva \& Ornat 2016; Valentine \& Harris 2016).

\section{INTERSECTIONALITY AND SOCIAL MOVEMENTS}

As many of the concept's originators emphasised, intersectionality is rooted in activism, 
and key intersectional theorists built on their engagement in social movements for inspiration and conceptual development (Cho et al. 2013). As an outcome of earlier debates in identity politics, intersectionality theory emerged as both a critique of the essentialist understanding of identity in some forms of identity politics (Grillo 1995; Anthias 2012) and an attempt to shift the focus away from individual identity praxis towards intersecting systems and structures of oppression (Bacchetta 2009; Collins \& Bilge 2016). Yet intersectional activism in itself is not devoid of contradictions and it is also from the realm of activism and movement organisation that intersectional theory is critically interrogated. Intersectional thinking has opened up the possibility of building solidarity across differences in coalitional platforms (Butler 2015; Collins \& Bilge 2016). By emphasising how individuals face an interlocking matrix of oppressions, individuals can be connected along various lines in their struggles against oppression, to combine in a 'universal rich with particulars' (Chun et al. 2013), as was recently demonstrated by the International Women's March (Doan 2017; Gökarıksel \& Smith 2017; Rose-Redwood \& Rose-Redwood 2017).

At the same time, intersectional claims also compromise the mobilising power of strategic essentialism in identity-based movements (Grillo 1995; Leachman 2016). Progressive social movements deploying strategically essentialist strategies do struggle to accommodate intersectional claims from within the movement (e.g. Black Lives Matter in the US have been criticised for ignoring the lives of Black Women; Western liberal feminists for ignoring or even contributing to the specific oppression of Women of Colour - see also Rose-Redwood \& Rose-Redwood 2017 on the Women's March), whereas intersectionality is sometimes deployed to imply divisive hierarchies of oppression (Aouragh 2019).

Despite intersectionality's roots in social movement activism, there has been little geographical work examining the opportunities, contradictions and difficulties of conducting intersectional activism. Here we review two key texts which have attempted to do this. In his study of the construction of intersectional solidarities between diverse Londoners and British coalminers during the historically significant Miners' strike in Britain in 1984/85, Kelliher (2017) has examined how key community infrastructures, such as feminist bookshops and LGBT Centres, helped articulate solidarity between differently positioned social groups with the striking miners. For him, the relationship between miners in Britain's coalfields and London's more multicultural and diverse working classes had been laid down over more than a decade before the strike and included the miners own support for striking Asian women workers at the Grunwick film processing plant in the 1970s. As Brown (2020) has argued, in his analysis of an attack on the apartheid-era South African embassy in London during a protest against the introduction of a Poll Tax on all adults in Britain in 1990, many expressions of intersectional solidarity are moments of coming together against a (perceived) common enemy, by diverse participants with intersectional experiences of multiple structures of oppression. Such events might be contrasted with more intrinsic expressions of coming together with across intersectional differences, as are discussed in many of the papers in this issue (e.g. Rahbari, Peterson, Pan \& Loopmans).

\section{THE FOCUS OF THIS COLLECTION}

This special issue engages explicitly with the political and the spatial by addressing how spatial structures and intersectional solidarities and activism coproduce each other (Roestone Collective 20142014; Featherstone 2017). It examines how intersectional relations of power, exclusion and solidarity are produced in doing (West \& Fenstermaker 1995) through and in a struggle over the making of everyday places (e.g. Featherstone 2012; 2017; Janská et al. 2017). As is emphasised by Oosterlynck et al. (2017, p. 11), the relations between identity, solidarity, and place making are intricate and underline the fundamentally political character of space:

Space is not a neutral background to these politics, but is a fundamental strategic property; it can be a source for identification and the construction of common reference frames (Martin 2003; 2013); it can 
become a focus of struggle (Castells 1983; Mayer 2003; Loopmans et al. 2012), or it can be a locale where relations of interdependence are forged and made explicit (Simone 2004; 2010; Routledge \& Cumbers 2009; Nicholls 2009; Featherstone 2012).

The plasticity of intersectionality and the variability of intersectional solidarities commands particular attention to the everyday practice of intersectional identity formation and politics (Valentine 2007; Vainikka 2015) and its geographical dimensions. Indeed, intersectional movements emphasise the relevance of specific places where coalitional labour such as meeting, interaction and discussion are facilitated, thus acting as a basis for coalition building across differences and across space; but they do not ignore the role of space in the reproduction of oppressions and exclusions.

In a key text from 2012, Michael Brown explored some of the limitations of geographical scholarship about intersectionality. He argued that geographical scholarship has tended to examine some intersectional relationships (such as those between gender, race and class) more than others and repeatedly expressed its anxieties about relationships beyond this triad of social categories, which it fails to adequately grapple with. This special issue cannot entirely escape those anxieties, but it does bring together a range of different intersectional relationships that are not always discussed alongside each other. Most papers discuss solidarity and exclusion in the light of the intersection of the popular triad gender, race and class, but also include religion, sexuality, health, nationality, and place. In presenting political struggles around sexuality and sexual health alongside debates about migrant solidarity and the placemaking of minority ethnic groups, the collection seeks to challenge and subvert 'paranoid readings' (Sedgwick 2003) of seemingly inescapable assemblages like 'homonationalism' in the contemporary world, and spatially situate them (Ritchie 2015). Our contributions recognise the strenuous movement work needed to build progressive intersectional solidarities, as much as the challenges offered by the spatial contexts of mobilisations (Siltanen et al. 2015; Rose-Redwood \& Rose-Redwood 2017). Yet we also explore conditions and possibilities for solidarity in and through always unresolved and imperfect intersectional collaborations.

Ladan Rahbari, in a discussion of World Hijab Day, a transnational action in solidarity with Muslim women against Islamophobia, explores the intricacies of intersectional solidarity and collaboration. She analyses the problems related to the decontextualised, a-spatial character of this internet campaign, and emphasises the need to connect the global virtual network with local places of mobilisation and encounter where the complexities of the intersectional oppression faced by Islamic women in different contexts can be discussed and contextualised.

Similarly, Pan and Loopmans emphasise the multiscalar and relational character of intersectional struggles. Analysing how national policies to contain HIV in China allowed homosexual men living with HIV to shape heterotopic places for LGBTQI + activism, they describe how oppression and empowerment combine through place-making politics in intersectional activism.

Peterson, Scott and Nessi analyse these intersectional place-making politics in more detail. Comparing the erasure of Black activists from the Cape Town Pride with the erasure of LGBTI from Black South African communities, Lwando Scott analyses the co-formation of space and intersectional oppression in South Africa. In a similar vein, Cecilia Nessi, in an analysis of lesbian spaces in Milan, emphasises how the co-formation of identity and place reinforce intersectional divisions between white, native Italian lesbian spaces and migrant lesbian spaces as places for solidarity. Melike Peterson on the other hand, in line with Pan and Loopmans, zooms in on how places function as catalysts for solidarity. In an ethnographic analysis of semi-formal meeting places in Glasgow, she discusses how everyday interactions across differences are political moments which can underpin mutual understanding and counter intersectional division.

\section{CONCLUSION}

To conclude, the various papers in this section do not only offer us insights in a wide diversity of contexts and intersectional 
solidarities. They also open up new agendas for future intersectional geographies of solidarity and activism. They point at a need to expand our academic endeavour in three interconnected directions.

First of all, our contributions show that intersectional solidarities do not emerge out of thin air. They are the result of geographically varied, intense movement labour. We need a better understanding of the role of meeting places and interpersonal communication in identity formation and mobilisation, as much as we should study more intensively how the globalising networks through which activism moves, translate and transform intersectional solidarities.

Second, several contributions show how we should also be more open to explore how oppression and empowerment, solidarity and conflict are often embedded in the same socio-spatial assemblage. Intersectional mobilisations are inherently contradictory and these contradictions, with their spatial expressions, are still not understood clearly enough.

Finally, the various contributions reveal how intersectional solidarities unfold between places and scales, territories as well as networks. The geographical literature on social movements has emphasised how we should acknowledge the diverse spatial dimensions of mobilisations (Nicholls 2009; Uitermark et al. 2012; Miller 2016). Integrating these insights into the analysis and theorising of intersectional solidarities and activism promises a third direction in which geographical studies of intersectionality could make progress.

\section{Acknowledgements}

The authors would like to express their gratitude to the members of the 'Solidarity in Diversity' research network, for the discussions that inspired this collection, and thank the FWO. Fonds voor Wetenschappelijk Onderzoek for the funding that made these discussions possible.

\section{REFERENCES}

Anthias, F. (2012), Intersectional What? Social Divisions, Intersectionality and Levels of Analysis. Ethnicities 13, pp. 3-19.
Aouragh, M. (2019), 'White Privilege'and Shortcuts to Anti-racism. Race Ẽ Class 61, pp. 3-26.

Bacchetta, P. (2009), Co-Formations: Des Spatialités de Résistance Décoloniales chez les Lesbiennes 'of Color' en France. Genre, Sexualité Ẽ Société 1. https://doi.org/10.4000/gss.810.

BArber, T. (2015), Performing 'Oriental' Masculinities: Embodied Identities among Vietnamese Men in London. Gender, Place E Culture 22, pp. 440-455.

Brown, G. (2020), 'Burn It Down!': Materialising Intersectional Solidarities in the Architecture of the South African Embassy during the London Poll Tax Riot, March 1990. Environment and Planning C: Politics and Space 38, pp. 233-250. https://doi.org/10.1177/2399654419857183

Brown, M. (2012), Gender And Sexuality I: Intersectional Anxieties. Progress In Human Geography 36, pp. 541-550.

Butler, J. (2015), Notes toward a Performative Theory of Assembly. Cambridge, MA: Harvard University Press.

Castells, M. (1983), The city and the Grassroots: A Cross-cultural Theory of Urban Social Movements. Oakland, CA: University of California Press.

Cho, S., K.W. Crenshaw \& L. McCall (2013), Toward a Field of Intersectionality Studies: Theory, Applications, and Praxis. Signs: Journal of Women in Culture and Society 38, pp. 785-810.

Choo, H.Y. \& M.M. Ferree (2010), Practicing Intersectionality in Sociological Research: A Critical Analysis of Inclusions, Interactions, and Institutions in the Study of Inequalities. Sociological Theory 28, pp. 129-149.

Chun, J.J., G. Lipsitz \& Y. Shin (2013), Intersectionality as a Social Movement Strategy: Asian Immigrant Women Advocates. Signs: Journal of Women in Culture and Society 38, pp. 917-940.

Combahee River Collective (1983), The Combahee River Collective Statement. In: B. Sмiтн, ed., Home Girls: A Black Feminist Anthology, pp. 264-274. New York: Kitchen Table, Women of Color Press.

Collins, P. \& S. Bilge (2016), Intersectionality. Cambridge: Polity Press.

Crenshaw, K. (1989), Demarginalizing the Intersection of Race and Sex: A Black Feminist Critique of Antidiscrimination Doctrine, Feminist Theory and Antiracist Politics. University of Chicago Legal Forum, pp. 139-167.

Davis, A. (1983), Women, Race and Class. New York: Vintage Books.

DoAn, P. (2017), Coming Out of Darkness and into Activism. Gender, Place Ẽ Culture 24, pp. 741-746. 
Featherstone, D. (2012), Solidarity: Hidden Histories and Geographies of Internationalism. London: Zed Books.

Featherstone, D. (2017), Afterword: Solidarities, conjunctures, encounters. In: S. OOSTERLYNCK, N. Schuermans \& M. Loopmans eds., Place, Diversity and Solidarity, pp. 165-176. London: Routledge.

Gökariksel, B. \& S. Smith (2017), Intersectional Feminism beyond US Flag Hijab and Pussy Hats in Trump's America. Gender, Place E Culture 24, pp. 628-644.

Grillo, T. (1995), Anti-essentialism and Intersectionality: Tools to Dismantle the Master's House. Berkeley Women's Law Journal 10, pp. 16-30. Hooks, B. (1984), Feminist Theory: From Margin to Center. Boston, MA: South End.

HOOKs, в. (1990), Marginality as a Site of Resistance. Out there: Marginalization and contemporary cultures 4, pp. 341-343.

Hopkins, P. (2018), Feminist Geographies and Intersectionality. Intersectionality in Feminist Geographies, Gender, Place and Culture 25, pp. 585-590.

Janská, E., K. Pauknerová, \& M. Koropecká (2017), Transnational Behaviour of Ukrainian Remitting Migrants. Tijdschrift voor Economische en Sociale Geografie 108, pp. 656-668.

Kelliher, D. (2017), Constructing a Culture of Solidarity: London and the British Coalfields in the long 1970s. Antipode 49, pp. 106-124.

KnApP, G.-A. (2005), Race, Class, Gender: Reclaiming Baggage in Fast Travelling Theories. European Journal of Women's Studies 12, pp. 249-265.

LEACHMAN, G.M. (2016), Institutionalizing Essentialism: Mechanisms of Intersectional Subordination within the LGBT Movement. Wisconsin Law Review, 2016, pp. 655-682.

Loopmans, M., G. Cowell \& S. Oosterlynck (2012), Photography, Public Pedagogy and the Politics of Place-making in Post-industrial Areas. Social E Cultural Geography 13, pp. 699-718.

Martin, D.G. (2003), 'Place-framing' as Placemaking: Constituting a Neighborhood for Organizing and Activism. Annals of the Association of American Geographers 93, pp. 730-750.

Martin, D.G. (2013), Place Frames: Analysing Practice and Production of Place in Contentious Politics. In: W. Nicholls, B. Miller \& J. BEAumont, eds. Spaces of Contention: Spatialities and Social Movements, pp. 85-99. Aldershot: Ashgate.

MAY, V.M. (2015), Pursuing Intersectionality, Unsettling Dominant Imaginaries. London: Routledge.
Mayer, M. (2003), The Onward Sweep of Social Capital: Causes and Consequences for Understanding Cities, Communities and Urban Movements. International Journal of Urban and Regional Research 27, pp. 110-132.

Miller, B. (2016), Spaces of Contention: Spatialities and Social Movements. London: Routledge.

Nicholls, W. (2009), Place, Networks, Space: Theorizing the Geographies of Social Movements. Transactions of the Institute of British Geographers 34, pp. 78-93.

Oosterlynck, S., N. Schuermans \& M. Loopmans, EDS. (2017), Place, Diversity and Solidarity. London: Taylor \& Francis.

Prins, B. (2006), Narrative Accounts of Origins: A Blind Spot in the Intersectional Approach? European Journal of Women's Studies 13, pp. 277-290.

Ritchie, J. (2015), Pinkwashing, Homonationalism, and Israel-Palestine: The Conceits of Queer Theory and the Politics of the Ordinary. Antipode 47, pp. 616-634.

Rodó-De-ZÁrate, M. (2016), Feminist and Queer Epistemologies beyond Academia and the Anglophone World: Political Intersectionality and Transfeminism in the Catalan Context. In: G. Brown \& K. Browne, ed. The Routledge research companion to geographies of sex and sexualities, pp. 155-164. Abingdon: Routledge.

Rodó-De-ZÁrate, M. \& M. Baylina (2018), Intersectionality in Feminist Geographies. Gender, Place E Culture 25, pp. 547-553.

Rodó-De-ZÁrate, M. (2017), Affective Inequality and Heteronormative discomfort. Tijdschrift voor Economische en Sociale Geografie 108, pp. 302-317.

Roestone Collective (2014), Safe Space: Towards a Reconceptualization. Antipode 46, pp. 1346-1365.

Rose-Redwood, C.A. \& R. Rose-Redwood (2017), It Definitely Felt Very White': Race, Gender, and the Performative Politics of Assembly at the Women's March in Victoria, British Columbia. Gender, Place Ẽ Culture 24, pp. 645-654.

Routledge, P. \& A. Cumbers (2009), Global Justice Networks: Geographies of transnational solidarity. Manchester: Manchester University Press.

SEDGwick, E.K. (2003), Touching Feeling: affect, pedagogy, performativity. Durham, NC: Duke University Press.

Siltanen, J., F. Klodawsky \& C. Andrew (2015), 'This is How I Want to Live My Life': An Experiment in Prefigurative Feminist Organizing for a More Equitable and Inclusive City. Antipode 47, pp. 260-279.

Silva, J. \& M. Ornat ( 2016), 'Wake up, Alice, This is Not Wonderland!': Power, Diversity and 
Knowledge in Geographies of Sexualities. In: G. Brown \& K. BRowne, ed., The Routledge research companion to geographies of sex and sexualities, pp. 185-194. Abingdon: Routledge.

Simone, A. (2004), People as Infrastructure: Intersecting Fragments in Johannesburg. Public Culture 16, pp. 407-429.

Simone, A. (2010), City life from Jakarta to Dakar: Movements at the Crossroads. New York: Routledge.

Uitermark, J., W. Nicholls \& S. LoOpmans (2012), Cities and Social Movements: Theorizing beyond the Right to the City. Environment and Planning A 44 , pp. 2546-2554.

VAINIKKA, J.T. (2015), Reflexive Identity Narratives and Regional Legacies. Tijdschrift voor Economische en Sociale Geografie 106, pp. 521-535.
Valentine, G. (2007), Theorizing and Researching Intersectionality: A Challenge for Feminist Geography. The Professional Geographer 59, pp. $10-21$.

Valentine, G. \& C. Harris (2016), Encounters and (In)tolerance: Perceptions of Legality and the Regulation of Space. Social E Cultural Geography 17, pp. 913-932.

Weldon, L. (2019), Power, Exclusion and Empowerment: Feminist Innovation in Political Science. Women's Studies International Forum 72, pp. 127-136.

West, C. \& S. Fenstermaker (1995), Doing Difference. Gender and Society 9, pp. 8-37.

Williams, E.L. (2014), Sex Work and Exclusion in the Tourist Districts of Salvador, Brazil. Gender, Place and Culture 21, pp. 453-470. 